International perspectives on the future of geography education: an analysis of national curricula and standards

Graham Butt and David Lambert

Taylor and Francis (Routledge) (2014)

https://radar.brookes.ac.uk/radar/items/eb523c68-2b26-428b-8ff5-ec59f06838a6/1/

This version is available:

Available on RADAR: 17.12.2015

Copyright (C) and Moral Rights are retained by the author(s) and/ or other copyright owners. A copy can be downloaded for personal non-commercial research or study, without prior permission or charge. This item cannot be reproduced or quoted extensively from without first obtaining permission in writing from the copyright holder(s). The content must not be changed in any way or sold commercially in any format or medium without the formal permission of the copyright holders.

This document is the published version. 


\title{
International perspectives on the future of geography education: an analysis of national curricula and standards
}

\author{
Graham Butt and David Lambert
}

\begin{abstract}
Geography as a school subject is expressed in a wide variety of ways across different national jurisdictions. This article explores some of the issues arising from attempts to represent geography as a subject for study in schools through the organisational structures offered by national standards and/or national curricula. It serves as an introduction to this Special Issue, which primarily concerns itself with the contemporary analysis of geography education in seven national settings across the globe.

We stress the importance of considering political, cultural, social and philosophical traditions when analysing the curriculum choices made for geography education. Although it may be assumed that geography as a disciplinary specialism is concerned with a body of knowledge that is common across the globe, the creative tensions generated between the disciplines, educational trends, and matters of social or policy concern play out differently - making comparisons across jurisdictions hazardous. Understanding this, we argue, is of great significance to those who plan and shape the geography curriculum. Despite the difficulties we hope to offer something more useful than a series of descriptions of geography teaching in different national settings. The purpose of this paper is to introduce a set of robust and irresistible arguments for the inclusion of the study of geography in schools. Geographical knowledge is a vital component of the education of young people across the globe, we argue, even though it may be expressed in different ways in different national settings.
\end{abstract}

\section{Introduction}

This special issue is concerned with analysing the ways in which geography is expressed in national curriculums, or standards, for primary and secondary schools in selected countries. Nothing in education stands still (Lambert 2013), and there seems to be little apparent stability about the ways in which school geography is currently defined in different national jurisdictions. Furthermore there are significant divergences, as well as commonalities, between these national settings in the ways in which they choose to represent geography in schools. Even the ostensibly straightforward matter of what is meant by 'in schools' lacks consistency between jurisdictions: for example, are schools privately or state funded; independent or 
under local (or even central) government control? These choices reflect political, cultural, social and philosophical traditions - an appreciation of which guides us to be circumspect about answering an important question such as 'where now, for school geography internationally?' But just because these are complicated matters is no reason not to pose the question.

\section{An analytical approach}

We have assembled analytical accounts of geography curriculums/standards from seven national settings. These are, very broadly, in a Euro-American 'sphere of influence', both in their approaches to education and their traditions of geographical study - although note that not every country represented in this collection is English speaking and we have contributions from well beyond an 'anglo-American 'heartland"! (cf Johnston 1979). Even so, we acknowledge from the outset that there is a strong case for another Special Issue to provide international analysis of school geography in systems that are very definitely not of the traditions privileged in this issue: from countries in the Islamic world maybe; or more systematically from Asia comparing geography in schools in Japan and China; or from the continents of Africa and South America.

The editors gave the authors invited to contribute to this Special Issue a concise, but flexible, 'steer' as to the expected content and conceptual reach of their papers. The intention of this publication is not only to outline the ways in which geography is expressed in the school curricula of different countries but also to offer analysis and/or reflection on why things have turned out as they have in particular settings. To support the writing process we asked contributors to refer to two of Bill Marsden's papers on geography in the curriculum (Marsden 1989, 1997), which we suggested might be helpful in providing an initial framework for the structure and content of papers in terms of the competing priorities of subject, educational trends and matters of social or policy concern (such as promoting good citizenship). Marsden was writing about the curriculum in England and indeed, twenty years ago - and thus his analysis may not 'translate' easily to other national jurisdictions today. We are also mindful that his analysis was at the level of aims and purposes (which we believe to be crucial) but relatively silent on matters of policy context, accountability and so on (but see Rawling 2001). Nevertheless, our hypothesis was that Marsden's work might serve as an appropriate conceptual reference for authors. We expected contributors to go beyond these guidelines, possibly to explore aspects of core/essential knowledge, powerful knowledge, the rationale applied for selection of curriculum content, or emergent capabilities approaches to conceptualising the curriculum (eg Lambert 2011), as appropriate to their national contexts. We reminded authors that the writings of Michael Young - on the nature of powerful knowledge, as well as his recent work with Johan Muller on alternative curriculum futures (Young and Muller 2010) - might also be of interest in framing responses.

We suggested that three key questions might be addressed: 
- How is geography in your national school setting ${ }^{1}$ best characterised in terms of its disciplinary hinterland, or heritage?

- In what ways have contemporary trends or innovations in educational thought impacted on geography, and in particular how these are expressed or configured in the standards/curriculum?

- In what ways is geographical thought and knowledge valued, or perhaps undervalued, in schools in relation to contemporary issues of cultural, economic, environmental, political and/or social concern?

Through addressing these questions we hoped that an analysis of the major influences on geography education in a range of different national settings would result. Embedded within these accounts would be considerations of three of the main forces which have shaped, to a greater or lesser extent, the (geography) curriculum:

- educational processes, including international concerns to express competences and 'transferable skills' in the curriculum designed to promote the generic idea of 'learning to learn';

- $\quad$ social and cultural issues, including the positioning of environmental concerns (including climate change), society matters such as intercultural understanding and more generally the role of geography in supporting moral and spiritual education; and

- the discipline of geography, including perhaps an exploration of the relationship that exists between geography expressed as a school subject on the one hand, and as a research discipline in Higher Education on the other.

\section{Scope and coverage: a review}

Attempts have previously been made to provide an international overview of the state of geography education in schools (see, for example, Gerber 2001, Rawling 2004). Scholars have also offered commentaries on school geography provision in different continents (see contributions to Lidstone and Williams 2006), or (more frequently) on the teaching of geography in various national jurisdictions (see contributions to Kent, et al, 2004). The ambition of such accounts and collections is laudable, but they end up in practice as inevitably flawed or incomplete. For one thing, the scope of coverage tends to be problematic - at the 'macro' scale it is difficult to provide a concise, scholarly account of the global 'state of play' with respect to geography education in schools, while at the 'micro' scale national subject updates sometimes occur frequently, and are so context specific that they can best be understood only in a patchy or partial manner. Furthermore, although national updates tend to be completed by individuals who have considerable experience and knowledge of their own educational setting, these only afford limited possibilities for direct comparisons between other national jurisdictions. Issues both of focus and rigour abound. As we outlined above, we have tried to circumvent some of these problems by giving authors a degree of 'steer' for their writing. Additionally, the

\footnotetext{
${ }^{1}$ In relation to children in the primary and secondary years (up to 16 years).
} 
countries selected for inclusion in this Special Issue (Australia, England, Finland, New Zealand, Singapore, South Korea, USA) exhibit certain levels of common understanding, we hope, of traditions and influences with respect to provision of geography education in their schools. Before we introduce these we provide in this section a brief overview of progress to date in providing international perspectives of geography education in schools.

In August 2004, as a contribution to the Symposium of the Commission on Geographical Education (CGE) in Glasgow, the British sub-committee of the International Geographical Union - Commission on Geographical Education (IGU -CGE) (in association with the Scottish Association of Geography Teachers) published Geographical Education - Expanding Horizons in a Shrinking World (Kent et al 2004). Described as 'a progress report on current trends in geographical education world-wide' (p.9) this publication aimed to draw out notable characteristics in the provision of school geography from a range of countries. Its final section 'National Updates' - featured fourteen shorter chapters offering a reflection on the 'state of play' of school geography in particular countries, or regions. In her preface to these chapters Eleanor Rawling (2004) notes that each author wrote to a set template, which included headings on the 'key issues and challenges' facing geography education in schools, and 'current and planned developments for the future' (p.167). Her overview of their findings on 'challenges' stressed:

- geography's uncertain place in the school curriculum, particularly at primary level.

- decline in the opportunities for high quality teacher education in geography, with a concomitant decline in the number of specialist teachers of geography

- $\quad$ problems arising from the growth of assessment and performance-led systems, often at the expense of curriculum development.

- the need to ensure geography is involved in technological developments (internet, multimedia, GIS)

- the need to address the public image of the subject, such that the public, students and policy makers recognised its potential as a school subject.

With respect to 'opportunities' many of the national updates highlighted several possibilities which, with the benefit of hindsight, may have proved in some case to be a double-edged sword. For example, that geography provided a vehicle for educating young people about the environment and sustainable development; that their school curriculums increasingly emphasised national identity, cultural heritage and the strengths of diversity; and that ICT had the potential to help develop knowledge, skills, competencies and approaches to teaching and learning. We are ambivalent to this list because, rather like extolling the importance of geography in 'delivering' numeracy or literacy skills in the primary school curriculum, it diverts our attention away from geographical knowledge. These arguments inadvertently undermine the case we often have to make in order to ensure that the earth as an object of study, and people's relationship with the earth as an object of thought, are seen as important in their own right, and essential components of the school curriculum. While Gerber's (2001) previous survey of geography in 31 countries led him to a 'cautious optimism' about geography's place in the school curriculum, Rawling's (2004) assessment was less sanguine - stressing the need to 'recognise the 
real threats to the subject' and to be prepared to 'take immediate action within our own communities' (p.169). Recurrent among these perceived threats were the growth of integrated studies, the rise of vocational education and the tendency towards more 'skills based' (rather than 'subject based') education in schools. Interestingly, this narrative of introspection was acknowledged to take place within the context of a vibrant and dynamic discipline of geography in universities and research institutions in several countries, leading to a separate discourse on the 'gap' between academic communities of school and college, and some soul searching over the nature of geography (see for example, Goudie 1993; Castree et al 2007; Stannard 2003; Bonnett 2008, Butt and Collins 2013).

Bill Marsden's (2005) provocation, in a guest editorial for a previous Special Issue of IRGEE, that geography was now 'the worst taught subject', echoed a famous statement at the time by Her Majesty's Chief Inspector of Schools, with respect to geography teaching in English primary schools (see Bell 2004). It served as a preface to a number of national perspectives on school geography (including comments from Argentina, Canada, England, Germany, Hong Kong, Hungary, the Netherlands and USA). Here the coverage was eclectic, the content often salutary - but the picture of geography education that emerged was not entirely negative. Thus, for example, although Marsden agrees that the contention about the standard of geography teaching is not 'entirely without foundation', he is 'seriously inclined to doubt its general validity' (p.1). Lidstone (2005) similarly notes a degree of correlation in the nature of (negative) responses from different countries, but can identify geography education's positive contribution to an 'enhanced concentration on transferable skills and the creation of ever more technologically based knowledge societies'(p.61) (although, see our previous caveats). Others identify the popularity of geography in schools, examples of upturns in student understanding and attainment, the growth of professional subject associations and the modernisation of curriculum development in geography.

John Lidstone's (2006) introduction to a substantial section devoted to 'Contemporary School Geography' in Geographical Education in a Changing World (Lidstone and Williams 2006) provides a similar commentary to Rawling's, completed two years earlier. Authors' contributions were made 'regionally' (Europe, North America, Australasia, East Asia and South America), with each section including a number of national perspectives. Lidstone noted that regional, national and international trends in geography education might owe much to 'policy borrowing' from particular countries - often reflecting previous colonial links. Significantly, former colonies of the UK were seen to maintain separate disciplinary studies for longer, whilst those under greater influence from the USA tended to adopt various 'social studies' in their school curriculums. It was felt that some countries wished (perhaps subconsciously) to emulate the social, educational, economic and political status of others, leading to the shape and content of their school subjects and curricula being strongly influenced by education systems, curriculum structures and subject content imported from elsewhere. Indeed, Lidstone (2004) had previously asserted that this often meant that the names of a relatively small group of geographical education theorists are cited in the work of curriculum designers and researchers in (so) many countries' (p.87). English-speaking jurisdictions are therefore highly influential in spreading curriculum and pedagogical ideas, and these are the ones (predominantly, but not exclusively) focused upon here. 


\section{Geography in school and the wider (policy) landscape.}

It is apparent that looking only 'inwardly' on the structure and content of the school geography curriculum - or indeed the curriculum of any school subject - is useful, but only to a degree. An appropriate analogy for this process, if not tempered by a more expansive view, is that of re-arranging the chairs on the deck of the Titantic. We may obsess about the details of the geography curriculum, but this is largely a wasted exercise if we do not take heed of the wider policy landscape in which the subject curriculum 'sits'. Our efforts to secure appropriate standards for geography education in schools, in our various national or state settings, are very important. However, political and ideological influences on the curriculum, the school system and the accountability environment in which it operates, must also be considered - and understood. This does not mean bowing unnecessarily to external agendas: as we noted earlier in this article it is a double-edged sword to 'justify' geographical knowledge in the curriculum in terms of literacy, numeracy, transferable skills or indeed 'good causes' such as citizenship or sustainability. But it does mean recognising that geography in the school curriculum is not a 'given' entity (in the way that some subjects are often deemed to be, like mathematics or science - although even in these cases there are fierce debates as to the form these subjects should take in school curriculum contexts). Thus, whilst geography as an idea will never disappear (unless we feel that the task of making sense of the world is complete or unnecessary) it is possible to imagine geographical knowledge being considered as inconsequential, and therefore undermined or reduced in an era of rapid policy innovation and change: at least it is if the arguments for its educational value are marginalised. Although for reasons we have explained earlier in this paper it is beyond us to provide secure and reliable arguments that transfer seamlessly between national jurisdictions, it is hoped that this Special Issue of IRGEE, by attempting a broadly framed analysis of national settings for school geography, will encourage robust and irresistible arguments for geography in school.

However, we do not underestimate the power of national policy directions to disregard even the most careful arguments and potentially to blow geography out of the curriculum water - at least for a time. In large swathes of Australia, geography in school has been invisible for a generation: but it is back in the form of a national curriculum for the first time, and the challenge, clearly, is to implement this to high quality standards with a workforce of teachers who have limited training in geography education. In the USA, despite the Geography for Life standards being in their second, fully revised edition (2012), the subject still has yet to secure Federal funding support: again, leaving the teaching force under-prepared and geography as a subject in a diminished state in all but a minority of schools. One of the most significant influences on the future of state schools in England - where the teaching force in secondary schools is largely specialist trained - is the high stakes (some would say draconian) accountability and inspection system, consisting of published league tables of examination results and regular inspections which are highly data driven. This had led to a 'deprofessionalisation' of teachers and pressures to 'teach to the test'. Adding to the marketisation of schooling in England (and of course elsewhere) is the rise of local governance and control, including over teachers' salaries and 'hiring and firing' policies. 
The 'academization' of schools in England - first introduced by New Labour in the early years of this century, but developed and accelerated by the Coalition government since May 2010 - is set to have a profound impact on what we understand by national curriculum standards. This is because by law academies do not have to teach the National Curriculum. Richard Hatcher (2012) has outlined how New Labour conceptualised academy schools - introducing a series of policies designed to lift poorly performing schools out of their challenging circumstances. This involved attracting financial sponsors to schools, who in turn would significantly influence the curriculum of the schools they supported. By the time New Labour left office in May 2010 they had established 203 academies. The policy of the current Coalition government in England is more radical. The first phase of their academization programme involved high performing state schools being given the option to convert (with or without a sponsor) to academy status - this soon shifted to forced conversions of underperforming secondary schools, and now primary schools, under more liberal sponsorship arrangements. The pace of change, as we write in mid 2013, is staggering. To date over half of state secondary schools in England have been converted, or are in the process of converting, into academies ${ }^{2}$.

Why is this important in our considerations of the place of geography in state schools internationally? Simply because it clearly illustrates the ways in which the future of geography (and all other school subjects), in England and elsewhere, is always closely tied to the national policy context. What might initially appear to be a relatively benign shift in education policy - more closely related to changing school funding and governance than curriculum matters - has the potential to radically affect the future of school subjects. Academies are autonomous schools, 'freed' from the previous 'control' of the Local Authority (LA) in which they sit (reversing the notion of schooling in England being 'a national system, locally administered', as has existed since the 1944 Education Act). Directly funded by government and sponsors (who may manage up to 30 schools each), academies own their school premises, establish individual admissions policies, employ staff that are free from national pay agreements and conditions of service, and importantly are not bound to teach the National Curriculum. If deemed 'outstanding' they require no sponsors and face no OfSTED inspections; if sponsored, it is the sponsors who may appoint the majority of the school's governors. Although released from local government control, academies draw additional funding from the LA budget - receiving greater amounts of money than other state schools and raising concerns about issues of democracy (Hatcher 2011). And note, as the law is currently configured the decision for a school to become an academy is irreversible. Both New Labour and Coalition governments have repeatedly claimed that the pupils in academies outperform those in other state schools, but evidence that they are more effective in raising attainment is hard to find - even from the Department for Education's (DfE) own research (Wrigley and Kalambouka 2012, Hatcher 2012, DfE 2012).

Academization is, in different forms, an international phenomenon (Forsey, Davies and Walford, 2008). It is likely to have a dramatic impact on the education that children receive - not least with regard to the curriculum subjects they are permitted or encouraged to study. With question marks against the effectiveness of academies in raising standards, and no legal requirement for pupils to study geography within what is now

\footnotetext{
${ }^{2}$ Other forms of state schools, all of which have no requirement to teach the National Curriculum, also exist such as 'Free' Schools, University Training Schools, Studio Schools, etc.
} 
(as in federal jurisdictions such as USA and Australia) a 'national' curriculum in name only, there are few guarantees that the future of geography education in English schools is secure. Indeed, evidence suggests that poorer performing academies tend to offer narrower, vocationally driven, curricula ${ }^{3}$ (Wrigley and Kalambouka 2012).

On the other hand, we argue from the evidence presented earlier in this paper that the need for geography constantly to justify its curriculum space has always been the case. There are no guarantees; but there is always a case to be made, especially when supported by a strong, cohesive and vibrant subject specialist community - such as Association of American Geographers (AAG) and the National Council for Geographic Education (NCGE) in the USA, Australian Geography Teachers Association (AGTA) in Australia, Eurogeo in Europe, and the Geographical Association (GA) in England, all of which are beginning to find ways to internationalise their work in curriculum development and teacher support. Thus, just as academization is an international phenomenon, so too is geography education - each taking different forms in different settings. The point is that there are general processes at play which can be understood, despite the fact that these are played out in unique local contexts. As geographers know better than most, the uniqueness of locality does not imply that they can only be understood as singularities. There are general (global) processes at work which we need to acknowledge and understand, even if these are realized in distinctive, unique ways in local contexts.

We have presented the case of academisation from an English national context, as an example of how an ideological and political backdrop to education, which is after all an international phenomenon, may have a disproportionate effect on the provision of geography education in schools. But we also point out that this does not imply powerlessness - as hopefully the papers in this issue illustrate.

\section{The contributions}

We have drawn together papers with almost a global reach (two each from Europe, Asia and Oceania, with one from North America), from jurisdictions influenced strongly by ‘Euro-American' traditions of geography and geography education.

Lambert and Hopkin provide an analysis of geography education in England from a 'possibilist' perspective. They draw on the work of Young and Muller (2010) to help outline the kind of geography curriculum that might be possible in English schools, acknowledging that their interpretation of the Geography National Curriculum (GNC) (revised for 2014) may be significantly different from that envisioned by politicians. The authors are careful to define their concept of 'curriculum', and to both trace and then analyse its various permutations and parameters - resulting in a re-statement of the essential curriculum question: 'what shall we teach?' Having analysed and evaluated the four iterations of the GNC which serves as a context for the

\footnotetext{
${ }^{3}$ Wrigley and Kalambouka's (2012) research identifies that in a case study of four academies, only $12 \%$ of pupils studied History or Geography at GCSE, compared to $57 \%$ in other schools locally. In one academy this research found that only a single pupil took history, with no one taking geography, at GCSE.
} 
Geographical Association's manifesto for geography education: 'A Different View' (GA 2009), they present their possibilist interpretation of the geography curriculum and the opportunities it may present for geography education post 2013. Their paper uses its novel 'futures' perspective on geography education, welcoming the knowledge turn in England as an opportunity for the resurgence of local curriculum making - where school teachers take back responsibility for what is taught from the state and its agencies.

Tani writes of the Finnish education system's 'success story', which has been widely reported with reference to the excellent results that Finland's students achieve on internationally benchmarked assessments, most notably, the Programme for International Student assessment (PISA). She acknowledges some of the difficulties associated with comparing performance internationally, and questions whether any elevation of the status of school geography on the 'back' of such results is entirely warranted. Interestingly, Finland's education policies have encouraged a national system of state-funded comprehensive education which is locally governed. It has a history of 'policy borrowing' from other jurisdictions and administers a highly-valued teacher education programme which attracts well qualified graduates, offering teachers the professional space (and trust) to develop their own curricula. Reflecting on Tani's paper, it is apparent that politicians from other national jurisdictions have picked very selectively from elements of the Finnish model to instil change in their own education policies: thus, the trend she notes towards a more skills based curriculum is probably not what ministers in England have chosen to pay regard to. Interestingly, she concludes that despite some evident freedoms for educators, there have been 'major problems in implementing broader pedagogical aims and contemporary social, cultural and environmental issues in the geography curriculum'.

Papers from Australia and New Zealand (Maude, Morgan) make up the contributions from Oceania. Maude describes how - in 2008 - the national, state and territory governments in Australia started to work towards the development of a common school curriculum, with the core geography curriculum being agreed in May 2013. He celebrates the effect this will have in elevating the status of geography in schools, with some states potentially making the subject compulsory up to Year 10, but is less pleased with the ways in which the geography curriculum was constructed, how its content was selected and the nature of the curriculum decision making processes. From New Zealand, Morgan reflects on a national history of geography curriculum making from the perspective of a relative newcomer - a position which he describes as being on the 'outside looking in' - which does at least enable looking at the landscape with fresh eyes. He highlights the social goals that lie at the heart of New Zealand's education system, targeting inequalities, under-achievements and the desire to raise human capital such that its people will be competitive participators in the global knowledge economy. Morgan believes that the geography curriculum is in need of renewal, despite the large degree of autonomy traditionally afforded teachers to engage in curriculum making, and is concerned by the dominance of assessment regimes and international comparisons of student attainment. The challenge, for Morgan, is that schools in New Zealand (and anywhere) must create geography curricula which help its students know and understand 'the complex forces that shape the economic, social and cultural landscapes in which they live'. 
From the Asian region papers have been offered by Lee and Butt (South Korea), and Chang (Singapore). In South Korea the direction of curriculum change is considered to be largely damaging to geography education in schools, with the current national and social aims for education effectively combining to side-line the teaching of geography. Here student numbers on school geography courses have declined, revisions to the geography curriculum have followed a competency model, and subject content is narrowly defined. However, there is recent evidence of grassroots movements among geography teachers, who are determined to take ownership of the structure and content of geography education. In the Singaporean context Chang, borrowing a phrase from Marsden (1989), discusses the role of 'significant power groups in academic geography and the state' which combine to shape students' experience of geography in schools. He notes that despite similar challenges to education being faced in many jurisdictions, particularly with respect to falling student numbers in geography, Singapore may be the 'envy' of countries where geography no longer exists as an independent subject. Curriculum development is facilitated by a 'strong partnership' of academic geographers and geography educators, within a strong state framework. However, Chang poses the provocative question of whether school geography in Singapore is now becoming too responsive to society's changing needs.

Bednarz, Heffron and Solem offer a rewarding analysis of geography education in schools in the United States of America through a lens focussed on the National Geography Standards, Geography for Life. First published in 1994, the Standards offer an interesting contrast to the ways in which many other jurisdictions have organised their provision of geography education - usually through a national curriculum, within which geography is represented in some way. The federal and state system in the US prioritises the delivery of education at the local level, with geography education forming only part of a broad social studies curriculum. The 2012 revisions to the Standards, reflecting changes in both educational practice and academic geography, are discussed with reference to an ambitious and visionary project to determine a 'Road Map' for $21^{\text {st }}$ century geography education. The US story is one of calm, persistent struggle to overcome identity issues both in schools and in the academy resulting from inadequate 'reward and recognition structures'. Will the Roadmap make a difference? One senses that this may depend on whether it switches on Federal funds - and this may depend on whether bringing geographical knowledge and geographical thought to addressing questions of society and environment are considered to be in the national interest.

What we now move onto is a tentative attempt to look across these contributions and identify possible international avenues to pursue based on our meta-analysis of the contributions.

\section{Internationalisation and learning with each other}

Attempts in the past to create forms of international solidarity in geography education have, in our view, met with only limited success. Bringing to mind Churchill's famous remark about British relations with the USA: it is as if we geographers too are 'divided by a common language'. Considerable effort was expended some twenty years ago now to create an international charter for geography education - and it is in many ways an impressive document (IGU-CGE 1992). But it is possible to look back and see that it attempted to impose a singular view of geography, and was therefore insensitive to unique context and the different traditions of 
geography in different settings - in social studies, in the humanities, or in the sciences. Secondly, and equally inadvertently, the international charter was arguably too 'internalist': in other words, in its focus on getting an agreement on how to express geography it was oblivious of broader trends and influences that need to be recognised and understood because they may undermine (or support) geography in whatever national or state form it takes.

The papers collected together in this Special Issue reflect many of the concerns highlighted by both Gerber (2001) and Rawling (2004) a decade or so earlier. Importantly many of the challenges are not faced solely by geography and geographers, but also by other curriculum subjects - but here we choose to concentrate less on the 'hurdles' that geography educationists (and others) must surmount, rather more on the ways in which we can plan ways forward for the meaningful (geography) education of young people.

Most authors identify, for their particular national settings, the need for geography to contribute something significant to the education of young people, who will increasingly be required to both engage with and compete in the global knowledge economy. They will also need to grasp some severe global ecological and environmental challenges. In essence the authors in this collection believe that studying geography, to borrow Butt's (2011a) assertion, can provide students with 'dynamic, inspirational, relevant and powerful ways of visualizing the world' (p.1). Chang references the potential of expressing this internationally through a 'capabilities approach': and indeed several of the authors in this collection (Lambert, Solem, Tani) have embarked on research to do just that. As we might expect, most national curricula and standards for geography require students to study aspects of the geography of their own country, to explore national identity and shared cultural heritage for example. But it is interesting how differently this priority looks between national settings.

The contributors recognise the influence of international comparisons of national student assessment data, highlighting its impact on the construction of national education policies (as well as the strong possibilities of encouraging policy borrowing between jurisdictions, often in the misguided hope of emulating similar results). There is broad agreement about the importance of geography teachers undertaking some form of curriculum making, and the significance of their subject content knowledge and understanding of theoretical structures to enable them to do so - the importance of keeping the influence of national curricula and standards within sensible parameters is realised within this context. It is also acknowledged by most authors that teachers will only be able to make worthwhile contributions to curriculum construction with appropriate professional training and development. Here the contributions of academic geographers are widely valued and thought, in most jurisdictions, to be essential. After all, school subjects that became disconnected from the disciplinary knowledge creating communities in universities would soon lack legitimacy.

Finally, it is clear from the papers offered here that the effects of globalization - with its impact on economic, social, cultural, political and economic geographies - should be both identified and taught through geography's contribution to the wider curriculum (see Butt 2011b). The discipline of Geography is well placed to offer insights into how globalization 'works', and its effects on spatial processes and global change. As a 'big idea' 
the concept of globalization has developed through contributions from interdisciplinary debate, within which geography in the academy and schools must play a part. What we are also left with is the sense that although it may be assumed that geography as a disciplinary specialism is concerned with a body of knowledge that is common across the globe, the creative tensions generated between the disciplines, educational trends, and matters of social or policy concern play out differently making comparisons across jurisdictions hazardous. Understanding this, we can conclude, is of great significance to those who plan and shape the geography curriculum. Despite the difficulties we hope to offer in the papers that follow something more useful than a series of descriptions of geography teaching in different national settings. The purpose of this paper is to introduce a set of robust and irresistible arguments for the inclusion of the study of geography in schools. Geographical knowledge is a vital component of the education of young people across the globe, we argue, even though it may be expressed in different ways in different national settings. 


\section{References}

Bell, D (2004) David Bell urges schools and the geography community to help reverse a decline in the subject. OfSTED press release, 24th November.

Bonnett, A (2008) What is geography? London: Sage.

Butt, G (2011a) Introduction in Butt,G (ed) Geography, Education and the Future. London: Continuum p1-11

Butt, G (2011b) Globalisation, geography education and the curriculum: what are the challenges for curriculum makers in geography? Curriculum Journal, Vol 22, 3, p.423-438.

Butt, G and Collins, G (2013) Can geography cross 'the divide'? in Lambert, D and Jones, M (eds) Debates in Geography Education. Abingdon: RoutledgeFalmer. p.291-301.

Castree, N, Fuller, D, and Lambert, D (2007) Geography without borders. Transactions of the Institute of British Geographers. 32 p.129-132.

DfE (2012) Attainment at Key Stage 4 by pupils in Academies 2011. Research Report DfE-RR223.

Forsey, M, Davies, S and Walford, G (2008) The Globalisation of School Choice? Didcot: Symposium Books.

Gerber, R (2001) The State of Geographical Education Around the World, International Research in Geographical and Environmental Education. Vol 10 (4) pp.349-362.

Goudie, A (1993) Schools and Universities - the Great Divide. Geography. 78 (4) p.338-339

Hatcher, R (2011) The struggle for democracy in the local school system. Forum. 53 (2) pp 213-224.

Hatcher, R (2012) The rise of academies, the end of the local authority? Joint Oxford Brookes University/Oxford University seminar. Oxford Brookes University. 20 November 2012.

International Geographical Union - Commission on Geographical Education (1992) The International Charter on Geographical Education. Accessed 10.9.13: www.igu-cge.tamu.ed/charters_1.htm

Johnston, R (1979) Geography and Geographers: Anglo-American Human Geography since 1945. London: Edward Arnold.

Kent, Rawling and Robinson (eds) (2004) Geographical education: expanding horizons in a shrinking world. Glasgow: SAGT with CGE.

Lambert D (2011) Reframing School geography: a capability approach, in Butt G (ed) Geography, Education and the Future, London: Continuum

Lambert, D. (2013) Collecting our thoughts: school geography in retrospect and prospect, Geography, 98, 1: $10-17$

Lidstone, J (2005) The Worst Taught Subject: International Perspectives on Bill Marsden's Guest Editorial. , International Research in Geographical and Environmental Education. Vol 14 (1) pp.61-62.

Lidstone, J and Williams, M (2006) Geographical Education in a changing world. Dordrecht: Springer

Marsden, W. E. (1989) “'All in a good cause': geography, history and the politicization of the curriculum in nineteenth and twentieth century England", Journal of Curriculum Studies 21 (6): 509-526 
Marsden, W.E. (1997) ‘On Taking the Geography Out of Geographical Education’ Geography 82 (3): 241-252

Marsden, W E (2005) Guest Editorial Reflections on Geography: The Worst Taught Subject? , International Research in Geographical and Environmental Education. Vol 14 (1) pp.1-4

Rawling, E (2001) Changing the Subject; the impact of national policy on school geography 1980-2000. Sheffield: Geographical Association.

Rawling, E (2004) Introduction: School geography around the world; in Kent, Rawling and Robinson (eds) (2004) Geographical education: expanding horizons in a shrinking world. Glasgow: SAGT with CGE. pp

Stannard, K (2003) Earth to Academia: on the need to reconnect university and school geography. Area, 35 p.316-332.

Wrigley, T and Kalambouka,A (2012) Academies and achievement: setting the record straight. accessed 21.3.13 www.changingschools.org.uk

Young, M. And Muller, J. (2010) Three Educational Scenarios for the Future: lessons fro the sociology of knowledge, European Journal of Education, 45, 1: 11-27 